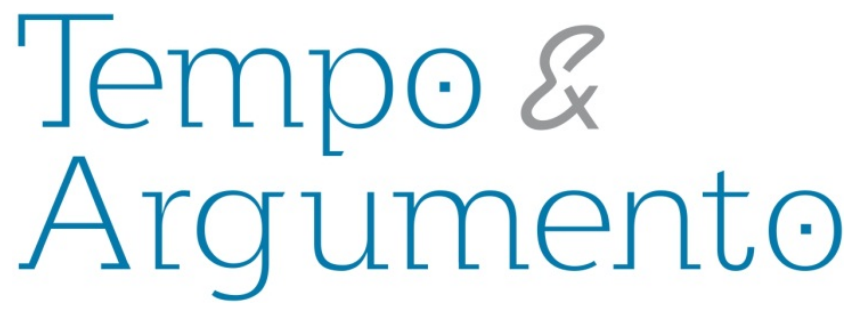

\title{
Angola: musicalidade, política e anticolonialismo (1950 - 1980)
}

\begin{abstract}
Resumo
Angola foi colônia de Portugal até 1975 e sua luta anticolonial possui importantes características no cenário africano, como: a produção literária de protesto; denúncias escritas por intelectuais; diferentes e divergentes movimentos sociais e políticos de luta pela liberdade; greves; desobediência civil; e, também, a musicalidade. Neste contexto, a música popular urbana auxiliou na construção de uma consciência nacionalista, contribuindo para a resistência e a luta anticolonial. Dessa forma, os registros fonográficos e as demais fontes coletadas e analisadas até o momento nos permitem acompanhar as transformações no conteúdo das letras das canções, que abordam temas como: cultura tradicional, resistência, luta anticolonial e a construção de um novo nacionalismo, proposto pelo governo socialista do Movimento Popular de Libertação de Angola (MPLA).
\end{abstract}

Palavras-chave: Angola. Musicalidade. Anticolonialismo. Independência. MPLA.

\author{
Amanda Palomo Alves \\ Doutoranda em História pela \\ Universidade Federal Fluminense \\ (UFF). Mestre em História pela \\ Universidade Estadual de Maringá \\ (UEM). Pesquisadora do Núcleo de \\ Estudos Contemporâneos (NEC) da \\ UFF e pesquisadora do Núcleo de \\ Estudos Interdisciplinares Afro- \\ Barsileiros (NEIAB) da UEM. \\ dinhapalomo@hotmail.com
}

\section{Para citar este artigo:}

ALVES, Amanda Palomo. Angola: musicalidade, política e anticolonialismo (1950-1980). Revista Tempo e Argumento, Florianópolis, v. 5, n.10, jul./dez. 2013. p. 373 - 396.

\section{DOI: $10.5965 / 2175180305102013373$}

http://dx.doi.org/10.5965/2175180305102013373

\footnotetext{
${ }^{1}$ Pesquisa financiada pela Coordenação de Aperfeiçoamento de Pessoal de Nível Superior (CAPES).
} 


\title{
Angola: musicality, politics and anticolonialism (1950 - 1980)
}

\begin{abstract}
Angola was a colony of Portugal until 1975 and his anti-colonial struggle has important features in African scenery, as the production of literary protest; complaints written by intellectuals; different and divergent social and political movements of struggle for freedom, strikes, and civil disobedience and, also, the musicality. In this context, the urban popular music helped in the construction of a nationalist consciousness, contributing to resistance and anticolonial struggle. Thus the phonograph records, and other sources collected and analyzed until the moment allow us to follow the changes in the contents of the lyrics of songs, covering topics such as traditional culture, resistance, anti-colonial struggle and the construction of a new nationalism, proposed by the socialist government of the Popular Movement for the Liberation of Angola (MPLA).
\end{abstract}

Keywords: Angola. Musicality. Anticolonialism. Independence. MPLA.

O presente artigo apresenta alguns resultados de nossa pesquisa sobre a música produzida em Angola, durante os anos de 1950 a 1980. As fontes e a literatura consultadas até o momento nos permitem perceber que a música popular angolana passou por diferentes fases, sobretudo, entre o período supracitado. Ao investigarmos o papel da canção na história recente daquele país privilegiamos as discussões travadas entre a história cultural e a história política, cujos interesses contemplam a ação dos 
indivíduos, grupos e movimentos sociais, assim como os modelos explicativos ou leituras sobre o passado em termos culturais e políticos. Nesta perspectiva, vale destacar que a noção de cultura política aparece pela primeira vez na historiografia francesa, no início dos anos 1990. Serge Berstein aponta que seu surgimento se inscreve na vasta corrente de renovação dos objetos e métodos da história política promovida na França a partir dos anos 1960, por René Remond e seus discípulos:

Tratava-se de tirar a história política do impasse em que se achava boa parte da produção histórica referente a esse campo da história, entre crônica factual erudita, nomenclatura de homens e organizações ou história militante autojustificativa, centrada principalmente nos movimentos extremistas de esquerda ou de direita, para substituíla por uma história portadora de sentido em que o político constituísse um elemento indissociável da evolução das sociedades tomadas em seu conjunto (BERSTEIN, 2009, p. 29).

Tal renovação consistia em aplicar à história política os enfoques e questionamentos das ciências humanas e socais, da ciência política e da história cultural, em particular, no campo das representações. Segundo Berstein, as abordagens empíricas dos fenômenos políticos mostram que os atos e comportamentos de atores políticos (como os cidadãos) se explicam mais frequentemente em função de um complexo sistema de representações, partilhado por um grupo expressivo dentro da sociedade. Tal sistema foi nomeado pelos historiadores de cultura política:

Os historiadores entendem por cultura política um grupo de representações, portadoras de normas e valores, que constituem a identidade das grandes famílias políticas e que vão muito além da noção reducionista de partido político. Pode-se concebê-la como uma visão global do mundo e de sua evolução, do lugar que aí ocupa o homem e, também, da própria natureza dos problemas relativos ao poder, visão que é partilhada por um grupo importante da sociedade num dado país e num dado momento de sua história (BERSTEIN, 2009, p. 30-31).

O conceito tem sido bastante utilizado pela história política recente. De acordo com Abreu, Soihet e Gontijo (2007, p. 13-14), ele permite explicar ou compreender o comportamento político de atores individuais e coletivos, privilegiando suas próprias 
percepções, lógicas cognitivas, memórias, vivências e sensibilidades². Rodrigo Patto Sá Motta, por sua vez, apresenta a seguinte definição de cultura política: “conjunto de valores, tradições, práticas representações políticas partilhadas por determinado grupo humano, que expressa uma identidade coletiva e fornece leituras comuns do passado, assim como fornece inspiração para projetos políticos direcionados ao futuro" (MOTTA, 2009, p. 21).

Ao atentarmos para os países africanos sabemos que durante muito tempo eles foram reféns de uma historiografia eurocêntrica, que escrevia a história com base em relatos dos colonizadores. Carlos Serrano (2008, p. 61-77) relata que tais descrições eram feitas, predominantemente, por estrangeiros e nenhuma destas pesquisas permitia uma visão objetiva sobre o significado de ser africano no contexto da luta pela libertação e conquista da independência dos povos africanos. Em sua obra "Angola: nascimento de uma nação", o autor realiza uma análise sucinta das pesquisas efetuadas na área de ciências humanas que se referem à África lusófona. De imediato, ele constata que esses estudos se fortalecem a partir dos anos 1960 devido a generalização da Luta de Libertação Nacional em todos os territórios do sistema colonial português. Comenta, ainda, que entre as décadas de 1960 e 1980, muitas análises acerca do espaço africano lusófono foram realizadas fora dele, ou seja, por cientistas sociais estadunidenses, ingleses, alemães, franceses, portugueses, canadenses, italianos, belgas e brasileiros.

$\mathrm{Na}$ fase contemporânea das pesquisas realizadas sobre Angola verificamos que são raras àquelas dedicadas à musicalidade. Tal cenário começa a se modificar a partir de 2008 com a publicação da obra Intonations: a social history of music and nation in Luanda,

\footnotetext{
${ }^{2}$ Peter Burke (2005, p. 135-138) salienta que seria um equívoco sugerir que os historiadores culturais tenham sempre ignorado a política, ou que os historiadores políticos tenham renegado a cultura. Ele salienta que havia lugar para a política na história cultural tradicional, seja na obra de J. Burkhardt sobre o Estado renascentista ou na de Marc Bloch acerca dos poderes curadores atribuídos aos reis da França e da Inglaterra. A expressão foi empregada pelos cientistas políticos na década de 1960 e parece ter entrado no discurso dos historiadores no final dos anos 1980 - a julgar pelos títulos de livros como The Political Culture of the Old Regime (1987), de Keith Baker. O estudo sobre a Revolução Francesa por Lynn Hunt, uma figura importante na Nova História Cultural, preocupou-se, principalmente, com a cultura política. Sua obra Politics, Culture and Class in the French Revolution (1984) focalizou as mudanças das "regras do comportamento político" e, de modo especial, as novas "práticas simbólicas". Outro exemplo do entrelaçamento entre história política e cultural é a obra coletiva do "Grupo de Estudos Subalternos", baseado na Índia e liderado por Ranajit Guha.
} 
Angola, from 1945 to recent times, da historiadora estadunidense Marissa J. Moorman. Sabemos que em diferentes momentos históricos existiram artistas que romperam com os códigos sociais ou políticos de sua época. Em processos revolucionários (ou não) sempre ocorreram formas contestatórias nas atividades artísticas. Ao pensarmos no continente africano percebemos que as manifestações de ordem político-musicais decorreram, sobretudo, em função das históricas lutas contra o colonialismo. No caso de Angola, colônia de Portugal até 1975, as formas de resistência foram várias. Destacamos a produção literária de protesto, a denúncia escrita por intelectuais, diferentes e divergentes movimentos de libertação, greves e, também, a musicalidade. Em relação aos movimentos culturais empreendidos, jovens intelectuais começaram a conscientizar parte da população dentro das raras possibilidades legais existentes e são nos centros urbanos que nascem - por meio de jornais escritos por intelectuais africanos - as primeiras denúncias do modo violento com que se impôs a dominação colonial. A partir de 1929, duas importantes associações são formadas: a Liga Nacional Africana e o Grêmio Africano (SERRANO, 2008, p.132-133).

Paralelamente a essa luta política de características locais, grupos de estudantes das diversas colônias que haviam emigrado para Portugal a fim de realizar seus estudos universitários (dada a ausência de instituições em seus países de origem) também se organizaram em torno de associações culturais legais. Durante os anos 1940 a 1950 jovens angolanos se reuniam em Lisboa com demais estudantes das colônias de Moçambique, Cabo Verde, Guiné-Bissau e São Tomé e Príncipe a fim de formarem organizações que combatessem o jugo colonial e em prol da independência. Nesta época surge em Lisboa o Centro de Estudos Africanos (CEA), que reuniu os principais futuros líderes dos movimentos pela descolonização das colônias portuguesas, como Amílcar Cabral, Agostinho Neto e Mário Pinto de Andrade. O governo de Salazar pôs fim às atividades do centro, mas não findou os encontros daqueles estudantes que deram continuidade às atividades na Casa dos Estudantes do Império (CEI), por meio de uma intensa atividade cultural de reabilitação do patrimônio histórico e cultural dos seus povos.

Em 1948, uma parcela da jovem intelectualidade luandense procurou se expressar por meio de poesia e textos literários que transmitiam a angústia dos angolanos e, ao 
mesmo tempo, reivindicavam os valores culturais negados pelo colonialismo. É deste período o surgimento da revista "Mensagem"3 e do movimento "Vamos Descobrir Angola", caracterizados por sua expressão literária e cultural. A revista e o movimento não possuíam um programa político de luta contra as autoridades coloniais, mas foram fundamentais enquanto elementos mobilizadores e de conscientização daqueles que futuramente iriam encabeçar a luta anticolonial.

Marcelo Bittencourt (2010, p. 134-135) esclarece que uma forma de driblar a censura e as limitações impostas pela ditadura salazarista foi a construção de uma visão nacionalista da cultura com o objetivo de: "recuperar o patrimônio africano, sistematicamente relegado pelas autoridades coloniais ao esquecimento". Havia uma tomada de consciência por parte desse grupo de intelectuais em relação à cultura hegemônica do poder colonial. O poeta Viriato da Cruz, um dos mentores do movimento, explica:

O movimento deveria retomar o espírito combativo dos escritores africanos dos fins do século XIX e dos princípios do atual. Esse movimento combatia o respeito exagerado pelos valores culturais do Ocidente; incitava os jovens a redescobrir Angola em todos os seus aspectos através de um trabalho coletivo e organizado; exortava a produzir para o povo; solicitava o estudo das modernas correntes culturais estrangeiras, mas com o fim de repensar e nacionalizar as suas criações tidas como positivas e válidas; exigia a expressão dos interesses populares e da autêntica natureza africana, mas sem que se fizesse nenhuma concessão à sede de exotismo colonialista. Tudo deveria basear-se na inteligência, na vontade, na razão e no senso estético africano (CRUZ apud SERRANO, 2008, p. 134).

Por meio dos jornais culturais e das formas literárias possíveis naquele momento histórico, a juventude angolana ansiava uma nova mensagem consolidada, especialmente, num sentimento nacional e numa consciência política nacionalista. Os escritores desta geração buscaram criar uma literatura diferenciada dos moldes europeus. Seus poemas possuíam um tom vibrante, distanciando-se da atmosfera bucólica que permeava a poesia europeia. Alfredo Margarido complementa:

\footnotetext{
3 A revista "Mensagem", criada em 1951, foi a primeira tentativa de maior expressão na busca pela reabilitação dos valores angolanos.
} 
Se Viriato da Cruz adopta muitas vezes estruturas poéticas portuguesas, é para as violentar, ao impor-Ihes uma construção angolana. A mudança não é somente temática no sentido de que ele tenta encontrar uma construção especificamente angolana no interior das estruturas da poética portuguesa. O recurso ao quimbundo, assim como às deformações fonéticas do português, não são uma tentativa folclórica ou populista, mas a busca duma semântica angolana (MARGARIDO, 1980, p. 339).

O mais importante em apreendermos e registrarmos deste período é que a ligação entre as associações culturais e a movimentação política foi o caminho possível para se buscar a conscientização e a organização necessárias para o início do combate ao colonialismo. Em relação ao cenário musical, uma fase importante se dá entre décadas de 1940 e 1950, onde compositores e intérpretes recuperaram elementos do regionalismo e a visão nacionalista da cultura foi um dos caminhos encontrados por aqueles que tentavam driblar a censura e as imposições da ditadura salazarista. Neste contexto de reivindicação, a produção musical do grupo “N'gola Ritmos”, formado em 1947 pelo músico Liceu Vieira Dias, foi salutar. Um dos objetivos era preservar a cultura angolana e, assim, compunham e interpretavam em kimbundu ${ }^{4}$ com a intenção de elevar a cultura dos seus antepassados e estabelecer uma relação entre o campo e a cidade, como podemos notar na canção abaixo “Mon’ Ami”. A letra relata o sofrimento de uma mãe que chora a morte do filho:

Talenu ngó! O Kituxi ki ngabange?

Talunu ngó! Maka mami ma jingongo!

Ngexile Kyá ni an'ami Kiyadi

Nzambi K’andalê Ngaxala ni umoxi

Ngibanga kyebyê?! Ngaxala ngoê ni umoxi

Ngibanga kyebi? O kituxi Ki ngabangyê?!

Mona wambote wajimbirila/

Ngidila ngoê! Ngibanza ngoê! Ay, mon'ami'

\footnotetext{
${ }^{4}$ Neste período, canções foram interpretadas em quase todas as línguas locais angolanas, mas o kimbundu foi predominante.

${ }^{5}$ Mon' Ami. Intérprete: N'gola Ritmos In: N'gola Ritmos. Vol. 2. Luanda - Lisboa: Alvorada, s/d. Lado A, faixa 1. "Vede só! Que pecado cometi/Vede só! As minhas palavras de dor!/Já tive dois filhos meus./Deus não quis. Fiquei com um./O que faço?! Fiquei só com um!/O que faço? Que pecado cometi?!/Um filho lindo se perdeu/Só choro! Só penso! Ai, filho meu!".
} 
Em entrevista à jornalista Milonga Santos, Amadeu Amorim, ex-integrante do “Ngola Ritmos", enfatizou o papel desempenhado pelo grupo e a reação das pessoas quando ouviam os intérpretes cantando em língua nacional: "quando cantávamos em kimbundu, as pessoas viravam a cara meio envergonhadas, chamavam-nos os mussequeiros. Parecia mal falar kimbundu; quem o falasse era considerado atrasado, gentio" (AMORIM, s/d ). A fala de Amorim nos remete a pensar que desde os princípios da colonização, a colônia foi dividida em dois campos extremamente distintos e desiguais: a sociedade colonial e a sociedade colonizada. Na situação colonial em África, a dominação foi imposta por uma minoria estrangeira em nome de uma superioridade étnica e cultural. Ao estabelecer categorias, como o "indígena"6, o "nativo" ou o "assimilado", o colonizador prescreve categorias de identidade e define o caráter da relação de si próprio com os que estão na situação de dominados (SERRANO, 2008, p. 47). Tal segregação facilitou a perseguição aos movimentos de libertação e aos movimentos culturais que ansiavam valorizar a cultura nativa. Esta repressão gerou um preconceito contra a língua e os ritmos musicais, então vistos como sinais de uma cultura não civilizada. Todavia, verificamos que eram vários os intérpretes cantando em Kimbundu e assim foram capazes de criticar o sistema colonial português. Neste sentido, a música figurou como uma importante forma de resistência.

Para além dos embates culturais, como os já destacados por Amadeu Amorim, consideramos fundamental enfatizar a censura e a repressão sofrida pelos músicos angolanos. No caso do "Ngola Ritmos"7, Amorim recorda: "Tínhamos que saber fugir à polícia e dos seus informadores, os chamados bufos, mas acabamos por fazer canções de absoluta reivindicação [...] É claro que fomos descobertos e, a seguir, perseguidos"

\footnotetext{
${ }^{6}$ A decisão portuguesa em avançar de fato com o projeto colonial em Angola implicou na elaboração de uma legislação para dar conta desse processo, que envolveu a classificação e delimitação dos espaços mais amplos da sociedade colonial angolana. Surgem, assim, os "civilizados" e os "indígenas", africanos não "assimilados" que, na avaliação das autoridades coloniais, não dominavam os códigos culturais europeus.

${ }^{7}$ Cumpre lembrarmos que a repressão atingiu outros compositores e intérpretes da época, como o músico Elias Dia Kimuezo. O uso do kimbundu em suas canções lhe custou várias interrogações e prisões por parte das autoridades coloniais, conforme ele mesmo relembra: "Em 1968 recebi uma notificação da PIDE, onde me interrogaram sobre o porquê de cantar em kimbundu e não em português" (NETO, 2010). A biografia de Elias Dia Kimuezo intitulada "A voz e o percurso de um povo" foi escrita pela jornalista e escritora angolana Marta Santos e publicada em 2012.
} 
(AMORIM, s/d). O nome do artista é citado no processo do músico Liceu Vieira Dias. O relatório, disponível nos arquivos da $\mathrm{PIDE}^{8}$ e datado em seis de outubro de 1959, informa:

Realizou-se no dia 2/10/1959, em casa do mestiço MACHADO, motorista da Lusolanda, uma reunião, da qual fizeram parte os componentes do grupo KIMBANDAS DO RITMO. Tratou-se de assuntos relativos à independência de Angola [...] Também se falou de que há dias mandaram perguntar ao LICEU VIEIRA DIAS e AMADEU AMORIM se eles continuavam a pertencer ao partido de independência ou se já tinham desistido e que eles tinham mandado dizer que não desistiam enquanto não vissem Angola em Liberdade [...] Luanda, 6 de Outubro de 1959. FRANCISCO ${ }^{9}$.

O mesmo informante, em abril de 1960, voltaria a informar à PIDE sobre as reuniões de grupos “com ideias subversivas e políticas” ligadas ao "N'Gola Ritmos”. No fichário encontra-se informada a relação entre o grupo musical e as lutas de libertação, como podemos observar: “Em 1958 fazia parte do grupo artístico angolano N'GOLA, tendo sido seu presidente em 1959. Alguns ensaios deste conjunto eram substituídos por reuniões do movimento para a Independência da Angola".

Dada a dificuldade em transmitir as canções por meio do rádio ou da televisão, o grupo se apresentava para amigos em aniversários, festas e espetáculos no Bairro Operário, local onde a banda foi formada. Sob a ótica de Marissa Moorman (2008, p. 6070), o "Ngola Ritmos" utilizou a música como uma "cobertura” para a política e foi fundamental para a relação entre cultura e nacionalismo. Em outras palavras, o sentido da nação foi forjado no cenário musical e, neste contexto, os musseques ${ }^{10}$ foram espaços fundamentais. "Musseque" é um termo originário do kimbundu e significa "lugar de

\footnotetext{
${ }^{8}$ Polícia Política Portuguesa (PIDE). Na segunda metade da década de 1950, consolidado o controle políticomilitar por Portugal, a PIDE se instalou em Luanda a fim de investigar e cessar as movimentações dos angolanos envolvidos com a divulgação de panfletos que continham mensagens anticoloniais. Norrie Macqueen esclarece que "qualquer manifestação de protesto nas colônias era sujeita a violenta repressão. Em 1957, a polícia política do regime abriu delegações em todos os territórios africanos e começou a organizar uma enorme rede de informadores" (MACQUEEN, 1998, p. 38).

${ }^{9}$ IAN/ TT, PIDE/DGS, Delegação de Angola, proc. 2418 GAB, NT-8096. Documento citado por FIÚZA, 2006, p. 177.

${ }^{10}$ Musseques são bairros pobres com casas feitas, geralmente, de papelão e lata.
} 
areia". Tal defnição foi cunhada por Ramiro Ladeiro Monteiro" em sua obra "A família nos musseques de Luanda", publicada em 1973. O crítico musical angolano Jomo Fortunato (2009) explica que os musseques seriam espaços de transição entre o universo rural e a cidade, um "laboratório" de canções que iria absorver as expectativas do ambiente da cultura urbana. As letras sinalizavam as experiências vividas no cotidiano, como a perda de pessoas queridas, problemas no trabalho e a precariedade das residências, como podemos notar na composição de Luiz Visconde, "Chofer de Praça”:

Mandei parar um carro de praça

Ansioso em ver meu amor

Chofer de praça então reclamou

Quando eu lhe disse que meu amor morava no subúrbio:

"Tempo chuvoso no subúrbio, não vou

Pois sou chofer de praça, não barqueiro”

Então-implorei: “Peço senhor chofer leve-me por favor

Ela não tem culpa de morar no subúrbio

Enquanto a chuva é obra de natureza" ${ }^{12}$.

Marissa Moorman entrevistou vários músicos e estes argumentaram que esta foi uma fase importante da música popular angolana. As canções compostas e interpretadas por eles voltavam-se para problemas sociais, políticos e, também, para o sofrimento que passavam.

Outro momento da música popular angolana se dá a partir dos anos sessenta do século XX, período em que o processo de descolonização é desencadeado em toda a

\footnotetext{
${ }^{11}$ Monteiro foi um administrador colonial na circunscrição de São Paulo, em Luanda. Em 1962 foi tranferido para os serviços de Centralizações e Coordenação de Informações, também em Luanda. O livro de Monteiro nos fornece características interessantes dos musseques, mas a literatura de José Luandino Vieira, especialmente a obra "Nosso musseque", nos apresenta uma abordagem diferenciada desses bairros. O autor, nascido em Portugal, passou sua infância e adolescência nos musseques de Luanda. Tal vivência fez com que sua produção literária testemunhasse um conhecimento vivido no universo desses bairros periféricos e avaliasse as consequências do sistema colonial. Em vinte de novembro de 1961 Luandino Vieira foi preso sob a acusação de atividades subversivas. Estava preso, aliás, quando escreveu grande parte dos seus livros, incluindo "Nosso Musseque”, redigido entre os anos 1961 e 1962.

${ }^{12}$ Chofer de Praça. Intérprete: Luís Visconde. In: Soul of Angola: anthologie de la musique angolaise (19651975). Luanda: Teta Lando Produções, 2001. 2 discos. Lado A, faixa 1.
} 
África. Em 1960, conhecido pela literatura que trata do tema como o "ano da África", dezoito ex-colônias proclamaram a independência no continente. Apesar da tentativa das forças repressoras do regime português em evitar a penetração dessa influência nas regiões africanas sob seu domínio, o clima de efervescência era pulsante (BITTENCOURT, 2002, p. 48-49) ${ }^{13}$. Nesta fase da história angolana predomina uma canção política de perfil "brigadista". As letras abandonam as sutilezas das crônicas cotidianas que retratavam as injustiças sociais, passando a acusar diretamente os portugueses e os seus aparelhos repressores. De acordo com Carlos Teles de Menezes Júnior (1998, p. 16-17) era um momento de intensa mobilização em que todos tinham que dar a sua contribuição à causa da independência.

Verificamos que muitas das canções produzidas a partir deste período assumem outra abordagem em relação ao que havia se produzido até então. Os registros fonográficos disponíveis por meio do Brasil nos permitem perceber que grande parte das composições se destinava ao apoio aos guerrilheiros, em particular, àqueles vinculados ao Movimento Popular de Libertação de Angola (MPLA). As letras revelam as influências político-ideológicas de alguns compositores inspiradas no marxismo ${ }^{14}$, matriz ideológica adotada pelo movimento. Constatamos, ainda, que o grande alvo de crítica são os colonialistas e os partidos políticos que possuíam orientações ideológicas antagônicas. A produção de artistas, como David Zé e Urbano de Castro é representativa deste contexto. As letras sinalizam um “elo" entre o movimento libertador e o povo, acusam a metrópole

\footnotetext{
${ }^{13}$ Destacamos que a ditadura salazarista implicava a impossibilidade de se travar a disputa política na esfera da legalidade, tanto na metrópole quanto nas colônias. Contra esse tipo de colonialismo adotado por Portugal, as opções não eram muitas. A luta teria que ser necessariamente clandestina e, consequentemente, pela via armada (BITTENCOURT, 2002, p. 48-49). Ao dissertar sobre a última fase do colonialismo Gervase Clarence Smith (1985, p. 201) atesta que em 1961, quando a revolta armada angolana abalou o império português até aos seus alicerces, muitos observadores esperavam que Salazar fosse derrubado e que se iniciasse a descolonização. Em vez disso, Salazar sobreviveu às tentativas do seu afastamento, optando por ficar e aguentar uma longa e desgastante guerra em África.

${ }^{14} \mathrm{Na}$ passagem da etapa de divulgação cultural para o momento de criação e organização de pequenos grupos de ação política clandestina, a influência do pensamento de orientação marxista foi basilar. Ele era transmitido aos angolanos independentistas por meio de trabalhadores marítimos exilados do regime e por intermédio de estrangeiros. O material a que tinham acesso incluía panfletos, revistas brasileiras e romances de escritores identificados com o marxismo, como Jorge Amado e Graciliano Ramos (BITTENCOURT, 2010, p. 136-137).
} 
e os movimentos antagônicos e fazem "propaganda" em favor do MPLA, com mensagens que mostram diretamente a orientação ideológica do movimento.

Urbano de Castro iniciou sua carreira, cantando sambas, boleros, merengues e sembas. Em 1970, aos vinte e nove anos de idade, aderiu à revolução anticolonial e neste mesmo ano foi preso pela PIDE. A canção "Angola liberté", editada em single, é desta época e teve um grande efeito mobilizador (FORTUNATO, 2012). Com o êxito da luta de libertação nacional pela conquista da independência, a música constituiu o veículo que elevou os ideais de progresso e emancipação política. Nesta época, a produção de David Zé foi emblemática (FORTUNATO, 2011). O cantor nasceu em vinte e três de agosto de 1944, em Kinfangondo, e em 1966 conheceu Urbano de Castro, fato que o influenciou a ingressar na carreira musical. Assim como grande parte dos cantores e compositores angolanos, sobretudo os que fizeram carreira no período colonial, David Zé abordou em suas canções fatos e experiências vividas por ele, destacando os conflitos sociais e a valorização dos costumes nacionais. Na fase final de sua carreira, compôs um número considerável de canções de cunho político, como "A luta continua", e "Mwangolé" (Guerrilheiro).

Com a emancipação política e o comando do país a cargo do MPLA, a partir de novembro de 1975, observamos o início de outra fase na música angolana. As canções deste período refletem um perfil panfletário, de caráter ideológico e legitimador do partido dirigente. As letras exaltam a força do povo angolano, denunciando os perigos do imperialismo. Os versos comunicam, também, a necessidade da construção de um projeto nacionalista em torno das propostas culturais, cuja característica seria, entre outras, a mitificação dos combatentes mortos. Seria uma nova época, marcada pelo socialismo e sem ligações com o passado, caracterizado pelo tribalismo, racismo e ignorância. Estas e outras questões podem ser observadas nos versos da canção “Independência", composta e interpretada por Mirol:

A independência está chegando

E a terra já vai resplandecer

Neste dia não vou mais chorar

Porque livre já serei 
Todo sofrimento acabará [...]

Viva o presidente Neto!

Viva o nosso poderoso MPLA!

Camaradas, abaixemos o imperialismo, neocolonialismo, racismo, tribalismo

E pendemos todos para o socialismo

Em que todos tenham os mesmos direitos

Sem distinção de raças ou sexos

Vamos toda a Angola!

Gritemos: MPLA ${ }^{15}$ !

Outro ponto a destacar é que com a chegada do MPLA ao poder a música popular se tornou uma das ferramentas de legitimação política e ideológica do movimento e da construção de um projeto nacional para Angola. Vários compositores contribuíram, compondo temas relacionados à causa nacionalista, relatando os grandes feitos de compatriotas nas ações políticas e na guerrilha e relembrando as datas decisivas para a luta anticolonial. Um álbum importante é “Angola Ano 1”, gravado em 1975 por Carlos Lamartine. Politicamente engajado, Lamartine fez parte de uma geração de músicos que elegeu como princípios básicos de criação artística a exaltação da história política de Angola, a liberdade, a independência e a defesa dos valores culturais do país. O artista começou a sua carreira em 1956, com o grupo "Kissueias do Ritmo" e entre os anos 1974 a 1977 sua obra ficou conhecida pelo grande público por meio de canções como: "Ene" (Eles), "Ó dipanda wondo tula kiá" (“A independência vai chegar”), "Zuatenu milela iá xikelela" ("Vistam-se de panos pretos”), “Kimbemba” (canção dedicada a Agostinho Neto), "Pala ku nu abessa ó muxima" ("Venho cantar para vos agradar"), "Etu tuana ngola tua solo kiá" (“Os filhos de Angola já escolheram o MPLA”) e "Ene ando builé” (Eles hão de se cansar). O disco mencionado acima contém doze faixas e na contracapa do álbum podemos ler as seguintes mensagens:

"A independência não se dá, conquista-se" e o heróico povo angolano bem sabe que assim é. Foi através da luta armada que conquistou a sua independência, com a sua perseverança e o sacrifício de muitos dos seus

\footnotetext{
${ }^{15}$ Independência. Intérprete: Mirol. In: A Vitória é Certa. Luanda, s/d. 1 disco.
} 
filhos mais queridos. O combate, a esperança e alguns desses heróis são evocados neste LP que, mais tarde ou mais cedo, se inscreverá como peça antológica da Revolução Angolana [...]. Existe sempre uma explicação para a tragédia e uma aceitação conformista do destino que ressalta em quase todas as obras que registradas, mas com uma viragem indiscutível a novos rumos. Assim, no âmago das canções e para lá do fatalismo tradicional que as caracteriza, encontramos a esperança na Revolução. E o tempo e as coisas passadas ganham nova dimensão, encontrando os caminhos da África e do Mundo ${ }^{16}$.

Os títulos das faixas do álbum sugerem temas parecidos aos das mensagens. Parece este ser o caso de "Faço-te este apelo camarada", composta e interpretada por Carlos Lamartine:

Faço-te este apelo camarada

Para te fazer ver a razão

Que o povo quer independência total

Onde não há ricos nem pobres

Nem escravos nem patrão

Este povo demais escravizado

Pegou em armas pra se libertar

Da opressão e da exploração

Do imperialismo internacional

Camarada sei que sentes no sangue

O apelo deste teu camarada

Abandone o tribalismo

Avante a Revolução!

Abandone o regionalismo

Avante a Revolução!

Vem pro seio do MPLA

Vem pro seio do povo angolano

Avante a Revolução

Pelo poder popular ${ }^{17}$.

\footnotetext{
${ }^{16}$ Não foi possível identificarmos a autoria dos textos mencionados no álbum, mas uma hipótese seria a de que pertencem ao próprio Carlos Lamartine.

${ }^{17}$ Faço-te este apelo camarada. Intérprete: Carlos Lamartine. In: Carlos Lamartine e Conjunto Merengue.
} 
A escuta da canção de Lamartine suscita duas questões: o didatismo revolucionário e o fato de que esta fase nacionalista se opõe à primeira, de exaltação do regionalismo para se chegar ao nacional.

Identificamos outros elementos nas letras das canções de compositores aliados ao MPLA. Várias destas canções ajudaram a edificar o culto aos heróis nacionais. Essa "mitifação" ${ }^{18}$ se desenvolveu pela ação em recuperar e reafirmar personagens históricos, como a rainha Nzinga e demais personagens que lutaram durante o processo de libertação de Angola. Estes combatentes (na maioria das vezes mortos durante a guerra) tornaram-se mártires. É o caso de "Hoji Ya Henda", “N’Gangula” e “Deolinda”, títulos de faixas do álbum "Glória eterna aos nossos heróis" ${ }^{19}$, de Santocas ${ }^{20}$, cuja produção teve um efeito mobilizador numa época em que os principais movimentos de libertação disputavam entre si a conquista do poder em Angola. As personagens citadas acima ilustram a capa do disco destacada abaixo:

Angola Ano 1. Luanda: CDA, 1975. 1 disco, Lado 1, faixa 2.

${ }^{18}$ Roland Barthes (1987) argumenta que a fala mítica pode ser formada por diversas representações: fotografia, cinema, esporte, publicidade, canções, entre outros. A característica fundamental do mito é a de ser apropriado por um determinado grupo ou classe. Na concepção do estudioso cabe à semiologia explicar as leis que regem os signos dos diferentes sistemas simbólicos. Para ele, não existem mitos eternos, uma vez que é a história que transforma o real em mito. Nestes termos, podemos depreender que o suporte do mito é a história, a experiência vivida, podendo ser utilizada para uma nova significação. De modo geral, o mito constitui uma mensagem e aparece como um construto de uma intenção ideológica.

${ }^{19}$ Santocas. Glória eterna aos nossos heróis. Luanda: Polo Norte, s/d. 1 disco.

${ }^{20}$ Santocas foi um cantor que revelava, de forma direta, os grandes ideais da luta pela independência, mostrando-se preocupado com questões como liberdade e o advento da independência do país. É de sua autoria as composições “Angola”, "Valódia” e “Massacre de Kifangondo”. FORTUNATO, 2011. 


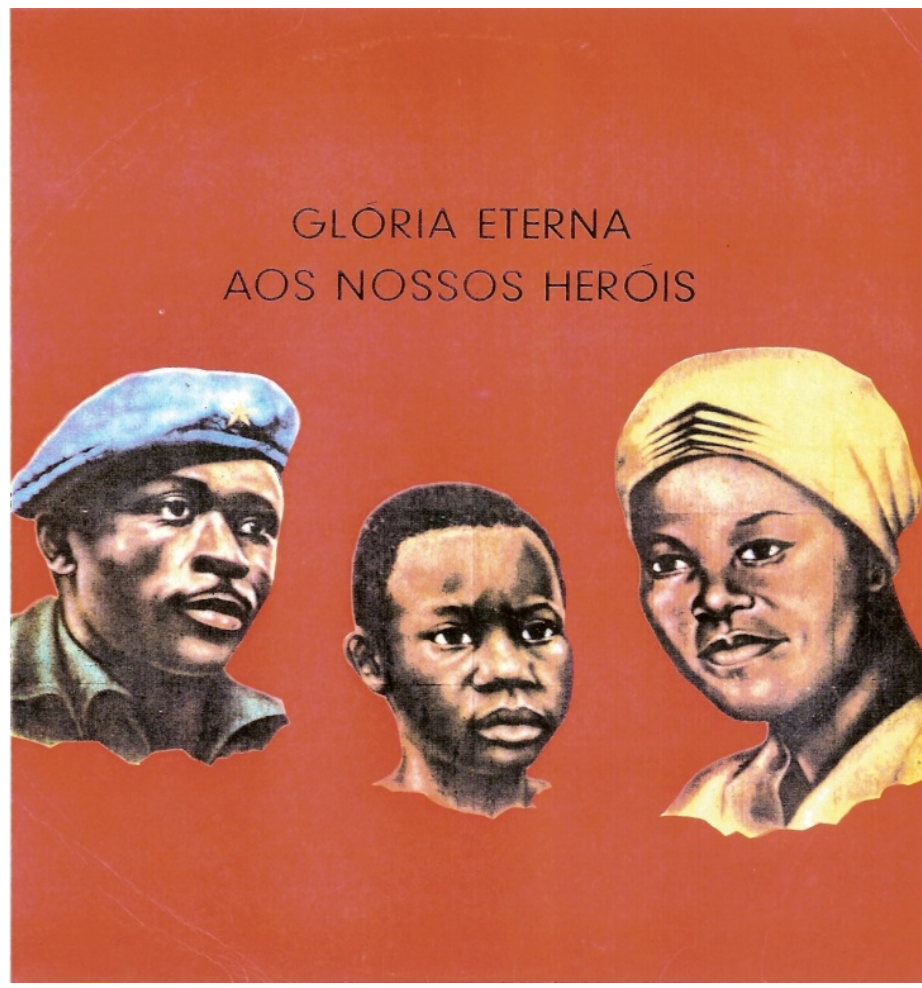

Imagem 1

Capa do disco "Glória eterna aos nossos heróis" (Santocas) Acervo particular de Carlos Teles de Menezes Junior

A composição da capa do disco é algo a destacar. Parece existir uma forte relação entre o conteúdo das canções contidas no álbum e na capa, onde é possível lermos na contracapa: "Uma pausa no ardor da Batalha para relembrar os Heróis tombados pela conquista da nossa Independência”. "Hoji Ya Henda” é uma canção composta em kimbundu, onde notamos o uso de instrumentos tradicionais angolanos como a dikanza ${ }^{21}$. Na canção, Santocas faz alusão às personagens já citadas, como Deolinda Rodrigues e N'Gangula, homenageado na canção abaixo:

N'Gangula morreu

Primeiro foi torturado

Depois foi interrogado

E no final esquartejado

Aquele pioneiro ${ }^{22}$ sofreu na carne

\footnotetext{
${ }^{21}$ A dikanza é um instrumento típico de Angola e se assemelha muito ao reco-reco.

${ }^{22}$ Ressaltamos que se era "pioneiro", era uma criança.
} 
Quando foi apanhado pelos lacaios

Ele foi torturado

N'Gangula preferiu dar a sua vida

No lugar de seus camaradas

N'Gangula

Você é o exemplo do nosso povo

O teu nome ficou na historia

E tu jovem pioneiro

Siga o exemplo de N'Gangula ${ }^{23}$.

Ao atentarmos para o planejamento da cultura nacional angolana, pelos responsáveis do Departamento Nacional e pelo Conselho Nacional de Cultural identificamos que os documentos fazem alusão a "marcha rumo ao socialismo", conforme a concepção marxista, matriz ideológica do MPLA. Além das personagens relembradas e cultuadas nas canções que já mencionamos, o Estado divulgou outras como “Cada cidadão é e deve sentir-se um soldado", interpretada por Santos Júnior:

Povo angolano, estamos em guerra

E cada cidadão é que deve sentir-se, necessariamente, um soldado

Esmagar a reação e derrubar os grupos fantoches

Neste momento, a principal tarefa: a reconstrução da nossa pátria

Camarada, vigilância às manobras reacionárias

As contradições são secundárias

O aspecto principal é a luta

Nós venceremos e a África também

A luta continua e a vitória é certa!

É certa

Em toda a África ${ }^{24}$.

\footnotetext{
${ }^{23}$ N'Gangula. Intérprete: Santocas. In: Santocas. Glória eterna aos nossos heróis. Luanda: Polo Norte, s/d. 1 disco. Lado A, faixa 4.

${ }^{24}$ Cada cidadão é e deve sentir-se um soldado. Intérprete: Santos Júnior. In: Vários Músicos. Progresso, Disciplina, Produção e Estudo: Luanda, s/d. 1 disco. Lado B, faixa 1.
} 
Bittencourt (2010, p. 139) destaca que no período pós-independência ganha espaço as ideias de construção do homem novo e de uma nova nação, que se daria pelo fim das etnias, dos regionalismos, do racismo e da exploração do homem pelo homem. Sob esta ótica, a música é um dos possíveis caminhos para percebermos a divulgação do novo projeto político do MPLA. Em “Avante o Poder Popular”, composição de Calabeto 25 , constatamos algumas das características mencionadas:

Se é antagonista o novo regime governamental

Então cuidados se você é branco, preto ou mulato

Não pense nisso e vamos construir

Se é reacionário, pense bem que uma atitude antipovo

Mas quem é que manda?

É o povo!

E quem é o povo?

É O MPLA!

Avante o poder popular

Avante!

Abaixo todas as manobras do inimigo ${ }^{26}$.

Algo que vem nos chamando a atenção está relacionado ao processo de composição das canções. Teriam os músicos desta fase "liberdade criativa” para produzir suas obras? Sabemos que a música e o ato de fazer música estão sempre permeados pelo político e toda criação artística acontece com base em uma reação que realmente comova o artista, mediante um contexto específico que o cerca. O fato de vários músicos cantarem propagando a importância da vitória do MPLA passaria pela orientação partidária oficial de reconstrução nacional? E ainda, havia, por parte do Estado, um projeto político-cultural específico para os músicos populares? Um caminho a trilhar seria o de pensarmos que as teorias baseadas no marxismo-leninismo apontam o trabalho

\footnotetext{
${ }^{25}$ António Miguel Manuel Francisco ‘Calabeto’ nasceu em abril de 1945. Com uma carreira iniciada na década de 1950, Calabeto possui um repertório onde se destacam os temas “Nzambi”, "Ngola Yami”, “Avante o Poder Popular", "Camarada Presidente” e "A vitória é certa”.

${ }^{26}$ Avante o Poder Popular. Intérprete: Calabeto. In: Vários Músicos. Progresso, Disciplina, Produção e Estudo: Luanda, s/d. 1 disco. Lado A, faixa 4.
} 
cultural como uma forma de luta ideológica. Assim, o primeiro passo para a criação de uma cultura nacional angolana seria a de estatizar as manifestações culturais, que contariam com o apoio oficial para a sua divulgação.

Após a independência de Angola, em 1975, a atuação de conjuntos musicais como o “Kissanguela”, teve um papel primordial. O “Kissanguela” foi constituído em 1974, em Luanda, pela seção cultural da JMPLA ${ }^{27}$. O objetivo principal do grupo era servir de veículo transmissor das orientações e da estratégia política do MPLA. A discografia do “Kissanguela” é constituída pelos álbuns "Vitória Certa”, “Agrupamento Kissanguela”, “Rumo ao Socialismo" e “Progresso, disciplina, produção, estudo" - títulos que revelam o compromisso político e partidário do conjunto, assim como as capas dos álbuns. "Hoje é dia de Revolução" é uma composição gravada pelo grupo e interpretada por El Belo. Seus versos informam:

Hoje é dia de Revolução

Hoje eu canto para Revolução

Revolução nas Américas

Na Ásia

Na África

Oh, África!

África mãe-pátria

Conquistada pelo mundo imperialista

Servir a Revolução não é ser racista

Nem tribalista

Nem oportunista

Mas é como consolidar o internacionalismo proletário

Hoje é dia de Revolução ${ }^{28}$.

A crítica estabelece comparações muito próximas entre os conjuntos “Angolenses" e "Kissanguela”, não apenas pela contemporaneidade na militância pela

\footnotetext{
27 Juventude do Movimento Popular de Libertação de Angola.

${ }^{28}$ Hoje é dia de Revolução. Intérprete: El Belo. In: Agrupamento Kisangela. Agrupamento Kisangela. Luanda: CDA, s/d. 1 disco. Lado A, faixa 1.
} 
causa revolucionária, mas, também, pelos temas das canções de caráter intervencionista. Outro agrupamento que merece destaque é o "Fapla-Povo", conjunto formado por artistas que se envolveram na luta em defesa do MPLA e entraram para as forças armadas. Na edição número 89 do Semanário "O Angolense” encontramos a seguinte matéria sobre uma das aparições do "Fapla-Povo":

Por louvável iniciativa da OMA e da JMPLA da Comissão Popular do Bairro Nelito Soares teve lugar sábado à noite, no Ngola Cine, uma sessão de música, poesia e dança angolanas com a participação dos conjuntos "Os Merengues" e "Fapla-Povo". Com o objetivo imediato de despertar as massas para a ação organizativa das várias sessões que compõem a Comissão do grande Bairro. O Conjunto "Os Merengues" exibiu música popular no seu estilo característico. O resto do espetáculo foi preenchido pelo conjunto "Fapla Povo", constituído por elementos do nosso exército. Integra alguns dos melhores executores instrumentais do nosso meio artístico e três das vozes mais populares de Angola: Santocas, David Zé e Artur Nunes. Artistas fardados, engajados política e culturalmente na Revolução, mobilizando as massas através da música que é mensagem e força poderosa ${ }^{29}$.

A leitura de artigos em jornais e revistas (como o destaca acima) e a escuta atenta dos registros fonográficos angariados até o momento têm nos feito refletir muito sobre os significados de música política que, em português, pode adquirir diferentes nomenclaturas: canção política de intervenção, canção de resistência, hino libertário, canção subversiva, arte de combate, música engajada ou, ainda, canção progressista. Este tipo de produção musical tende, no geral, para questionamentos dos sistemas sociais e políticos estabelecidos e sua condição se dá pelo contexto social que a incorpora e a identifica (IKEDA, 1995, p. 11-17). Ao visualizarmos a sociedade com todas as suas contradições, podemos percebemos o uso da música no sentido político e ideológico.

Os diversos modos de contestação de um processo de dominação (como o colonialismo em Angola) visam à transformação da sociedade e figuram como uma importante forma de identidade e resistência. As canções compostas e interpretadas por músicos angolanos, entre as décadas de 1950 a 1980, nos levam a depreender que uma organização musical não ocorre e nem se estabelece num vazio temporal e espacial, ao

\footnotetext{
${ }^{29}$ Matéria publicada no Semanário O Angolense, n89, 21 de agosto de 1976, p. 37. Não foi possível
} identificarmos o autor do texto. 
contrário, a preferência no uso de determinados elementos da linguagem musical está associada à visão de mundo do compositor e do intérprete. Nestes termos, é preciso atentar para as peculiaridades presentes no processo de criação de uma canção, que envolve uma realidade histórica específica, afinal, como bem nos informa Mikhail Bakhtin (2004), buscar a apreensão das "formas concretas dos textos" $3^{0}$, que são sociais e históricas, é alcançar, também, o homem, a sociedade que o constitui e é constituída por ele.

\section{Referências}

ABREU, Martha; SOIHET, Rachel; GONTIJO, Rebeca (Org.). Cultura política e leituras do passado: historiografia e ensino de história. Rio de Janeiro: Civilização Brasileira, 2007.

ANGOLENSE, n 89, 21 de agosto de 1976, Luanda, p. 37.

BERSTEIN, Serge. Culturas políticas e historiografia. In: AZEVEDO, Cecília; ROLLEMBERG (Orgs) et. al. Cultura política, memória e historiografia. Rio de Janeiro: Editora FGV, 2009.

BARTHES, Roland. Mitologias. São Paulo: DIEFEL, 1987.

BAKHTIN, Mikhail. Marxismo e filosofia da linguagem. São Paulo: Hucitec, 2004.

BITTENCOURT, Marcelo. Angola: tradição, modernidade e cultura política. In: REIS, Daniel Aarão. (Org.) et al. Tradições e modernidades. Rio de Janeiro: Editora da FGV, 2010.

BITTENCOURT, Marcelo. Estamos juntos: o MPLA e a luta anticolonial (1061-1974). 2002. Tese (Doutorado). Universidade Federal Fluminense, Pós-Graduação em História, Niterói, 2002.

BURKE, Peter. O que é história cultural? Rio de Janeiro: Jorge Zahar, 2005.

FIÚZA, Alexandre Felipe. Entre um samba e um fado: a censura e a repressão aos músicos no Brasil e em Portugal nas décadas de 1960 e 1970. Tese (doutorado) - Universidade do Estado de São Paulo, Faculdade de Ciências e Letras de Assis. Assis, 2006.

\footnotetext{
${ }^{30}$ Não poderíamos findar este artigo sem mencionarmos as valiosas contribuições do filósofo russo Mikhail Bakhtin. Para ele, o texto não é exclusivamente verbal, podendo ser qualquer conjunto coerente de signo, seja qual for sua forma de expressão (pictórica, gestual, musical, etc.). O texto é a manifestação do enunciado, é uma realidade imediata, dotada de materialidade, que advém do fato de ser um conjunto de signos.
} 
FORTUNATO, Jomo. Angola: o percurso musical de Urbano de Castro. Jornal de Angola. 16 de janeiro de 2012. Disponível em:

<http://jornaldeangola.sapo.ao/17/o/o_percurso_musical_de_urbano_de_castro $>$. Acesso em março de 2012.

FORTUNATO, Jomo. Músico David Zé - a lenda da canção. Jornal de Angola. 03 de janeiro de 2011. Disponível em: <http://jornaldeangola.sapo.ao/>. Acesso em abril de 2012

FORTUNATO, Jomo. Processo de formação da música popular angolana. Jornal de Angola. 19 de outubro de 2009. Disponível em:

<http://jornaldeangola.sapo.ao/17/35/processo_de_formacao_da_musica_popular_angola na>. Acesso em abril de 2012.

FORTUNATO, Jomo. Santocas. Jornal de Angola. 19 de setembro de 2011. Disponível em: http://jornaldeangola.sapo.ao Acesso em abril de 2012.

JUNIOR, Carlos Teles de Menezes. O nacionalismo musical angolana. Monografia apresentada ao Programa de Pós-Graduação em História da Universidade Cândido Mendes - Centro de Estudos Afro-Asiáticos, Rio de Janeiro, 1998.

IKEDA, Alberto Tsuyoshi. Música política: imanência do social. Tese (doutorado) Universidade de São Paulo, Escola de Comunicações e Artes. São Paulo, 1995.

MACQUEEN, Norrie. A descolonização da África portuguesa: a revolução metropolitana e a dissolução do império. Lisboa: Editorial Inquérito, 1998.

MARGARIDO, Alfredo. Estudos sobre literaturas das nações africanas de língua portuguesa. Lisboa: A regra do jogo, 1980.

MOORMAN, Marissa Jean. Intonations: a social history of music and nation in Luanda, Angola, from 1945 to recent times. Athens, Ohio: Ohio University Press, 2008.

MOTTA, Rodrigo Patto Sá. Desafios e possibilidades na apropriação de cultura política pela historiografia. In: MOTTA, Rodrigo Patto Sá (Org.). Culturas políticas na história: novos estudos. Belo Horizonte: Argvmentvm, 2009.

NETO, Flávio - Entrevista Elias Dia Kimuezo. Do kimbundu inocente à consciência revolucionária. Novo Jornal, 25 de junho de 2010.

SANTOS, Milonga. Entrevista - Amadeu Amorim: a herança do N'gola Ritmos deve ser preservada. In: Casa de Angola, s/d. Disponível em:

<http://www.casadeangola.org/arquivo/Cronicas/NGOLARITMOS/ngola.html>. Acesso em março de 2012. 

SMITH, Gervase Clarence. A últir
1975). Teorema. Lisboa, 1985.

SERRANO, Carlos. Angola: nascimento de uma nação - um estudo sobre a construção da identidade nacional. Luanda: Edições Kilombelembe, 2008.

SMITH, Gervase Clarence. A última fase do colonialismo. In: O III Império Português (1825-

\section{Discografia}

Avante o Poder Popular. Intérprete: Calabeto. In: Vários Músicos. Progresso, Disciplina, Produção e Estudo: Luanda, s/d. 1 disco. Lado A, faixa 4.

Cada cidadão é e deve sentir-se um soldado. Intérprete: Santos Júnior. In: Vários Músicos. Progresso, Disciplina, Produção e Estudo: Luanda, s/d. 1 disco. Lado B, faixa 1.

Chofer de Praça. Intérprete: Luís Visconde. In: Soul of Angola: anthologie de la musique angolaise (1965-1975). Luanda: Teta Lando Produções, 2001. 2 discos. Lado A, faixa 1.

Faço-te este apelo camarada. Intérprete: Carlos Lamartine. In: Carlos Lamartine e Conjunto Merengue. Angola Ano 1. Luanda: CDA, 1975. 1 disco, Lado 1, faixa 2.

Hoje é dia de Revolução. Intérprete: El Belo. In: Agrupamento Kisangela. Agrupamento Kisangela. Luanda: CDA, s/d. 1 disco. Lado A, faixa 1.

Independência. Intérprete: Mirol. In: A Vitória é Certa. Luanda, s/d. 1 disco.

Mon' Ami. Intérprete: N’gola Ritmos In: N'gola Ritmos. Vol. 2. Luanda - Lisboa: Alvorada, s/d. Lado A, faixa 1.

N’Gangula. Intérprete: Santocas. In: Santocas. Glória eterna aos nossos heróis. Luanda: Polo Norte, s/d. 1 disco. Lado A, faixa 4. 
Recebido em: 04/09/2013 Aprovado em: 01/11/2013

Universidade do Estado de Santa Catarina - UDESC

Programa de Pós-Graduação em História - PPGH

Revista Tempo e Argumento

Volume 05 - Número 10 - Ano 2013

tempoeargumento@gmail.com 